\title{
Temperature Stress Affects Survival and Antibiotic Susceptibility of Pathogenic and Indicator Bacteria in Drinking Water Dispensing System
}

\author{
O.O. Adebisi, T.O. Agbabiaka, T.M. Kayode-Isola, and F.O. Otuyelu
}

\section{ABSTRACT}

Point-of-use water treatment and dispensing systems are becoming common features in middle-to-upper class homes and public spaces. However, their effectiveness at providing potable water is yet to be substantiated. In this study, the effect of temperature stress $\left(\right.$ cold $\approx 10^{\circ} \mathrm{C}$ and hot $\approx 78^{\circ} \mathrm{C}$ ) on survival of three pathogenic (Salmonella typhi, Shigella dysenteriae, Vibrio cholerae), a nuisance (Proteus vulgaris) and the indicator (Escherichia coli) bacteria was evaluated in water dispensers. Individual test organism was spiked into pre-sterilized distilled water in a $25-\mathrm{L}$ dispenser bottle. The bottle was fitted and the machine set on to allow the organisms acclimatized for 30 mins before samples were collected. The holding temperatures apparently had an immediate significant inhibitory effect $(p<0.05)$ on the pathogens, being greater in dispensed hot water. Effect of cold temperature stress was least on Escherichia coli. While Shigella dysenteriae and Vibrio cholerae were completely inactivated in dispensed hot water, there were some levels of resuscitation of the other organisms that were initially stressed by either the hot or cold temperature after just $1 \mathrm{~h}$ of cooling to room temperature. The re-inactivation was significant $(p<0.05)$ in the dispensed cold water for Salmonella typhi and Vibrio cholerae. With exception of Shigella dysenteriae, other organisms exhibited varied susceptibility $(5-11 \mathrm{~mm})$ to six of eight antibiotics; this appeared to increase following the temperature stress. However, increased resistance to augmentin, nitrofurantoin and tetracycline was observed in some temperature-stressed strains, particularly Salmonella typhi and Vibrio cholerae as well as Escherichia coli. The findings indicate that, while hot or cold temperature may have an immediate inhibitory effect on microbial loads and antibiotic susceptibility, the unwholesome practice of drinking dispensed water several hours after should be discouraged.

Keywords: antibiotic susceptibility, indicator bacteria, temperature stress, water dispenser

\section{INTRODUCTION}

The potential of water to harbour microbial pathogens and subsequently cause illness is well documented [1]. Incidence of coliform bacteria, particularly Escherichia coli [2], [3], pathogenic bacteria, such as Vibrio sp., Salmonella typhi and Shigella [4] and the opportunistic bacteria, Proteus vulgaris [5], in drinking water has been extensively reported. This makes the quality and safety of drinking water an important public health issue [6], [7]. In 2014, the World Health Organization (WHO) estimated that $80 \%$ of all communicable infections are linked to use of water of poor microbiological quality [8].

Small-scale or point-of-use treatment systems are now replacing municipally-operated chlorine treatment systems as major source of drinking water. One of these alternative point-of-use water treatment and dispensing systems that
Published Online: June 20, 2020

ISSN: $2684-5199$

DOI : 10.24018/ejbio.2020.1.3.38

\section{O.O. Adebisi*}

Department of Microbiology, Faculty of Life Sciences, University of Ilorin, Nigeria.

(soji-olusegun@unilorin.edu.ng)

T.O. Agbabiaka

Department of Microbiology, Faculty of Life Sciences, University of Ilorin, Nigeria.

(to.agbabiaka@unilorin.edu.ng)

T.M. Kayode-Isola

Department of Biology, Adeniran Ogunsanya College of Education, Nigeria.

(woletayo_2005@yahoo.co.uk)

F.O. Otuyelu

Department of Microbiology, Faculty of Life Sciences, University of Ilorin, Nigeria.

(frankotuyelu1@gmail.com)

*Corresponding Author have become common features in the middle-to-upper class homes and public spaces is the water dispensing machine. While there is limited empirical data to validate this, a general belief among the users of water dispensing machine is that the water is microbiologically safe. However, their effectiveness at providing potable water remains to be evaluated.

Hence, in this study, the effect of temperature stress (cold $\approx 10^{\circ} \mathrm{C}$ and hot $\approx 78^{\circ} \mathrm{C}$ ) on the survival of pathogenic (Salmonella typhi, Shigella dysenteriae, Vibrio cholerae), a nuisance (Proteus vulgaris) and the indicator (Escherichia coli) bacteria was evaluated in a water dispensing machine. The aim was to assess the nature of the effect of temperature at which water is dispensed on bacteria. And if the effect is only inhibitory, what risk is involved in the common practice of collecting water from the dispenser and leaving for a while before drinking. The ancillary objective was then to evaluate 
if the survival of certain pathogens after the temperature stress alters their antibiotic susceptibility.

\section{MATERIALS AND METHODS}

\section{A. Culture and Media}

Nutrient agar, nutrient broth, MacConkey agar, thiosulfate citrate bile salts sucrose (TCBS) agar, cystine lactose electrolyte deficient (CLED) agar, and SalmonellaShigella agar (SSA) were purchased from either Oxoid, UK or Merck Chemicals, UK. The multi-disc antibiotic strips were obtained from Fishers Scientific, UK. All culture media were prepared according to manufacturer's instruction and following standard microbiological procedures. Sterilization was by autoclaving at $121^{\circ} \mathrm{C}$ for $15 \mathrm{mins}$, except otherwise stated in the media preparation manuals.

The test organisms, Escherichia coli, Vibrio sp., Proteus vulgaris, Salmonella typhi, and Shigella sp., used were obtained from the Culture Collection of the Department of Microbiology, University of Ilorin, Kwara State, Nigeria. To reactivate the test organisms preserved in TSA-glycerol slant cultures and stored at $-70^{\circ} \mathrm{C}$, inoculums were sub-cultured on nutrient agar. Upon incubation for $18 \mathrm{~h}$ at $37^{\circ} \mathrm{C}$, the plates were observed for visible growth and a distinct colony was picked and sub-cultured. Subsequent sub-culturing of the isolates was carried out on selective-differential media; MacConkey agar (for Escherichia coli), SSA (for Salmonella typhi and Shigella), TCBS (for Vibrio cholerae) and CLED (for Proteus vulgaris), respectively.

Distinct colonies of the individual organism were picked from the appropriate selective media and inoculated into separate nutrient broth flasks $(200 \mathrm{ml})$ and incubated for 48 $72 \mathrm{~h}$ on an orbital shaker $(100 \mathrm{rpm})$ to allow for aeration of the flasks. Harvesting broth-free cell pellets was carried out by centrifugation $(3500 \mathrm{rpm})$ for $10 \mathrm{mins}$. The cell pellets were re-suspended in sterile phosphate buffer solution (PBS: $8 \mathrm{~g} \mathrm{NaOH}, 0.2 \mathrm{~g} \mathrm{KCl}, 1.44 \mathrm{~g} \mathrm{Na}_{2} \mathrm{HPO}_{4}, 0.24 \mathrm{~g} \mathrm{KH}_{2} \mathrm{PO}_{4}$ in 100 $\mathrm{ml}$ of distilled water) and the centrifugation process repeated three times until a clear supernatant was obtained. This ensured the complete extraction of broth remnants from the cells. Finally, the purified cell pellets obtained were resuspended in $\mathrm{PBS}$ and stored at $4^{\circ} \mathrm{C}$ for a duration not exceeding 3 days before use in the survival experiment.

The cell loads of the purified culture were estimated using the McFarland's standards [9] and adjusted where necessary to give approximately $10^{8} \mathrm{cfu} / \mathrm{ml}$. The optical density (OD) determination was set at a wavelength of 600 $\mathrm{nm}$, using a Genesys-20 spectrophotometer.

\section{B. Evaluation of Effect of Temperature Stress on Survival of Test Organisms}

An aliquot $(10 \mathrm{ml})$ of the cell culture was introduced into $990 \mathrm{ml}$ sterile distilled water previously aseptically placed in the dispenser bottle to give approximately cell concentration of $10^{2} \mathrm{cfu} / \mathrm{ml}$. After thorough mixing, $1 \mathrm{ml}$ of the contaminated water was withdrawn and used to determine the initial concentration of bacterial cells in the solution. The bottle was mounted on the dispenser machine (Binatone WTD-1301) and the button switched on for the machine to attain stable temperatures for the cold and hot water outlets. Thereafter, these temperatures were maintained for 30 mins for acclimatization. This was done to evaluate the effect of the temperature stress on the organisms. Water was aseptically collected from the cold and hot water outlets and duplicate aliquots $(1 \mathrm{ml})$ were withdrawn and inoculated on the appropriate agar plates to monitor the survival of the test organisms following $0.5 \mathrm{~h}$ exposure to temperature stress. Incubation was at $37^{\circ} \mathrm{C}$. Plates were observed after $24 \mathrm{~h}$ and enumerated after $48 \mathrm{~h}$.

Further, to investigate whether the effect of the temperature stress on the bacterial cells is static (i.e. momentary and reversible) or cidal (long-lasting or irreversible), the dispensed water samples were dispensed into sterile glass container with sealed lids and left on the workbench at room temperature for $1 \mathrm{~h}$. Aliquot $(1 \mathrm{ml})$ was then inoculated on appropriate agar plates as described previously. This was carried out to mimic a common behavior observed among the users of water dispensing machine. The experiments were run on four (4) different occasions with duplicate plates made from each sample to give a total of eight (8) bacterial counts for each test organism. The average of these data with its standard error of mean are reported.

\section{Assessment of Effect of Temperature Stress on Antibiotic Susceptibility of Test Organisms}

The antibiotic susceptibility of both unstressed and temperature-stressed strains was evaluated using KirbyBauer disc diffusion method [10] in accordance to the recommendations of National Committee for Clinical Laboratory Standards [9], with little modification. This procedure was carried out only for culture plates that showed visible growth. Briefly, immediately after the plates were enumerated, sterile inoculating swaps were used to pick the colonies and carefully spread to cover the surface of solidified sterile Mueller-Hinton agar (Difco) plates. The multi-disc antibiotic strips were then placed on the seeded plates and incubated at $35^{\circ} \mathrm{C}$ for $18-24 \mathrm{~h}$. The strips include the following eight antibiotics: amoxicillin (AMX), 25 $\mu \mathrm{g}$; augmentin (AUG), $30 \mu \mathrm{g}$; cotrimoxazole (COT), 25 $\mu \mathrm{g}$; gentamycin (GEN), $10 \mu \mathrm{g}$; nitrofurantoin (NIT), $100 \mu \mathrm{g}$; nalidixic acid (NAL), 30 $\mathrm{g}$; ofloxacin (OFL), $10 \mu \mathrm{g}$; and tetracycline (TET) $50 \mu \mathrm{g}$. Clear zones of inhibition were measured was recorded after 24 and $72 \mathrm{~h}$. This is to determine if the susceptibility of the stressed strains is momentary or long-lasting. This experiment was run on two (2) different occasions and the mean values reported.

\section{Statistical Analysis}

The means and standard errors of mean (SEM) were determined from data for the bacterial survival after temperature stress and compared for the various treatment regimens using MS Excel 2013 for Windows. Analysis of variance (ANOVA) test was carried out using SigmaStat v3.5 (IBM SPSS Inc., Chicago, IL, USA) to determine the effect of temperature stress on bacterial survival in water. ANOVA tests were performed at $p>0.05$ for normality and equal variance and the test significant was set at $p<0.05$. 


\section{RESULTS AND DISSCUSION}

\section{A. Effect of Temperature Stress on Bacterial Survival in Water Dispensing System}

Before the main experiments were set up, preliminary analysis showed that it takes about 4-6 mins for the average cold $\left(10^{\circ} \mathrm{C}\right)$ and hot temperatures $\left(78^{\circ} \mathrm{C}\right)$ to be reached in the dispenser machine. It is important to note that depending on a number of factors including, the brand and model type of the dispenser machine, the optimum cold and hot temperatures and the time taken to achieve these may vary. Another preliminary experiment was conducted to estimate the time that both the dispensed cold and hot waters adjusted to the ambient temperature $\left(\mathrm{ca} .27^{\circ} \mathrm{C}\right)$. It was observed that, while it often took a longer time for the hot water temperature to cool down, the cold water readily normalized to the ambient temperature. This may be due to the high humidity in our laboratory at the time of the experiment, coupled to the fact that the samples were collected in glass containers, which quickly absorbed heat from the surrounding.

The effect of temperature stress on the survival of the test organisms is presented in Fig. 1. Generally, irrespective of the dispensing outlets, at every run of the experiment, there were reductions (1-2 log) in bacterial loads following $0.5 \mathrm{~h}$ exposure to the temperature stress. In particular, significant decreases $(p<0.05)$ in the cell counts of the pathogens Salmonella typhi, Shigella dysenteriae and Vibrio cholerae, with apparently complete inactivation were observed in the dispensed hot water, at all times of sampling. Unlike the cold dispended water, the effect of the hot temperature was immediately significant and long-lasting on Shigella dysenteriae and Vibrio cholerae. While there was appreciable resuscitation of cell growth for all the three pathogens in the cold dispensed water as well as for Salmonella typhi in the dispensed hot water following reacclimatization to room temperature, there was no reinactivation of cells of Shigella dysenteriae and Vibrio cholerae in the dispensed hot water (Fig. 1). However, the re-inactivation was significant $(p<0.05)$ in the dispensed cold water for Salmonella typhi and Vibrio cholerae.

Compared to the pathogens, the temperature stress was less pronounced on the indicator bacteria Escherichia coli. The effect of cold temperature stress was least on Escherichia coli. Notably, of all the test organisms, the nuisance bacteria Proteus vulgaris exhibited the most resistance to the temperature stress (Fig. 1). Results indicated some level of resuscitation of Escherichia coli and Proteus vulgaris initially stressed by either the hot or cold temperature after just $1 \mathrm{~h}$ of cooling to room temperature.

To understand if the temperature stress on the bacteria is momentary and reversible, the dispensed water was allowed to cool to room temperature. In this study, one hour was used because it was the approximate time that both the cold and hot water would normalize to and acquire the temperature of the ambient environment, under the conditions in our laboratory. Most of the users also interviewed said they usually do not drink dispensed cold or hot water after such a period mainly because it would have lost either its coldness or warmness, and not necessarily because they feel it is no longer safe for drinking.

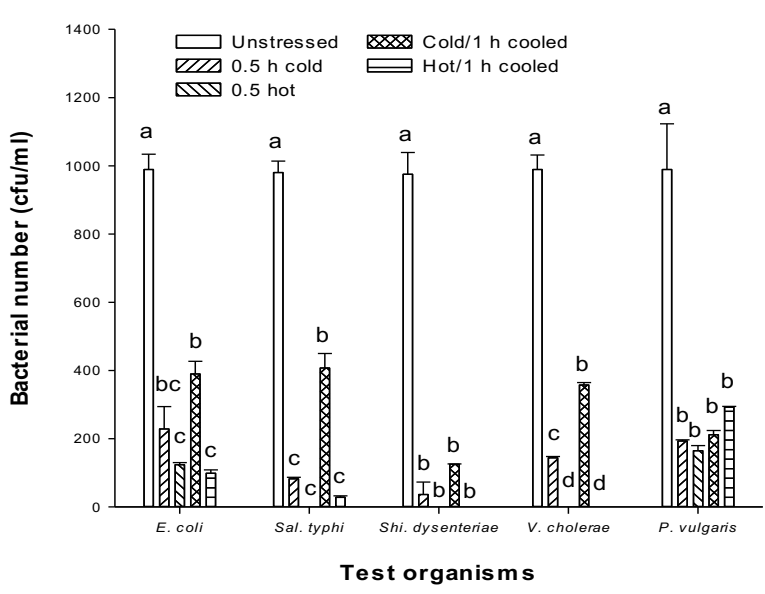

Fig. 1: Effect of temperature stress $\left(\operatorname{cold} \approx 10^{\circ} \mathrm{C}\right.$; hot $\left.\approx 78^{\circ} \mathrm{C}\right)$ on survival of test organisms in water dispensing machine

It is not surprising that population count of the test isolates from water dispensed through the hot tap is much lower compared to that obtained from the cold tap as heat, dry or moist, is used in both sterilization and disinfection and is the basis for a lot of established treatment processes including boiling and pasteurization. Similarly, temperature represents a critical environmental cue that can mediate changes in growth, development and pathogenesis [11]. Moist heat treatment, the process replicated by dispensing through the hot tap, albeit for a shorter period, kills organisms by degrading nucleic acids, denaturing enzymes and other essential proteins with the possibility of cell membrane disruption [12]. Salmonella typhi, Shigella sp., Vibrio sp., all waterborne pathogens, were particularly susceptible to temperature in this study. Previous studies [13], [14] have alluded to this.

This result lends credence to refrigeration as being capable of reducing drastically microbial count, with the obvious limitation being that it is only bacteriostatic, not bactericidal. The implication of this is that, should the quality of the packaged water be compromised from the factory, if the water is dispensed through the cold tap, its safety cannot be guaranteed especially in immunocompromised patients. Also dispensing the water through the hot tap and subsequently leaving it to cool further compromises its integrity as bacterial regrowth phenomenon is a high risk [15]. Other factors include machine conditions, servicing interval [16], filters [17], socioeconomic status, the presence of very young children, type of enterprise (service or industrial) [18] amongst others have been implicated as influencers of microbial population loads.

Many bacteria, including a variety of important human pathogens, are known to respond to various environmental stresses by entry into a novel physiological state, where the cells remain viable, but are no longer culturable on standard laboratory media.

\section{B. Antibiotic Susceptibility of Temperature-stressed Bacteria in Water Dispensing System}

Fig. 2 shows the changes in antibiotics susceptibility of the test organisms following the temperature stress. Results of the antibiotics susceptibility profiling further reinforce the already established notion of tetracycline as a redundant antibiotic though, amoxicillin and cotrimoxazole performed 
poorer in comparison for temperature-stressed strains. The temperature-stressed strains recovered from the cold outlet were particularly resistant to amoxicillin, cotrimoxazole, nitrofurantoin, nalidixic acid, augmentin, and tetracycline implying that these antibiotics would not constitute a good treatment regime for infections resulting from these organisms with the virulence factors seemingly unabashed by these antibiotics. A similar observation, but on a smaller scale, was observed for aliquots taken after an hour.

On the other hand, majority of the isolates, recovered via the hot water tap, were apparently stressed and highly sensitive to most of the antibiotics which is not quite surprising as virulence is often coupled to sensing physiological temperatures [11]. This observation is, however, not true at all times for all organisms, as elevated temperature leads to expression of bacterial virulence genes encoding type III secretion systems and adhesins in Yersinia sp. and some other pathogens [19]. The prospect that temperature stress protects, to some extent, against aminoglycoside in Escherichia coli, Acinetobacter baumannii and Pseudomonas aeruginosa have been raised. It was also suggested that $A$. baumannii would be better able to withstand streptomycin challenge in a scenario where it is pre-treated at $45^{\circ} \mathrm{C}$ for 30 mins [20]. We feel a plausible explanation to this observation is that the targets of these antibiotics, already damaged by temperature stress, are not essential for the survival of the organisms, and their previous damage implies there were no readily available targets for the antibiotics. While the findings of the previous reports differed considerably from our present observation, we feel, it does not undermine the validity of our finding as the test organisms, temperature and duration of exposure varied greatly from the previous works.
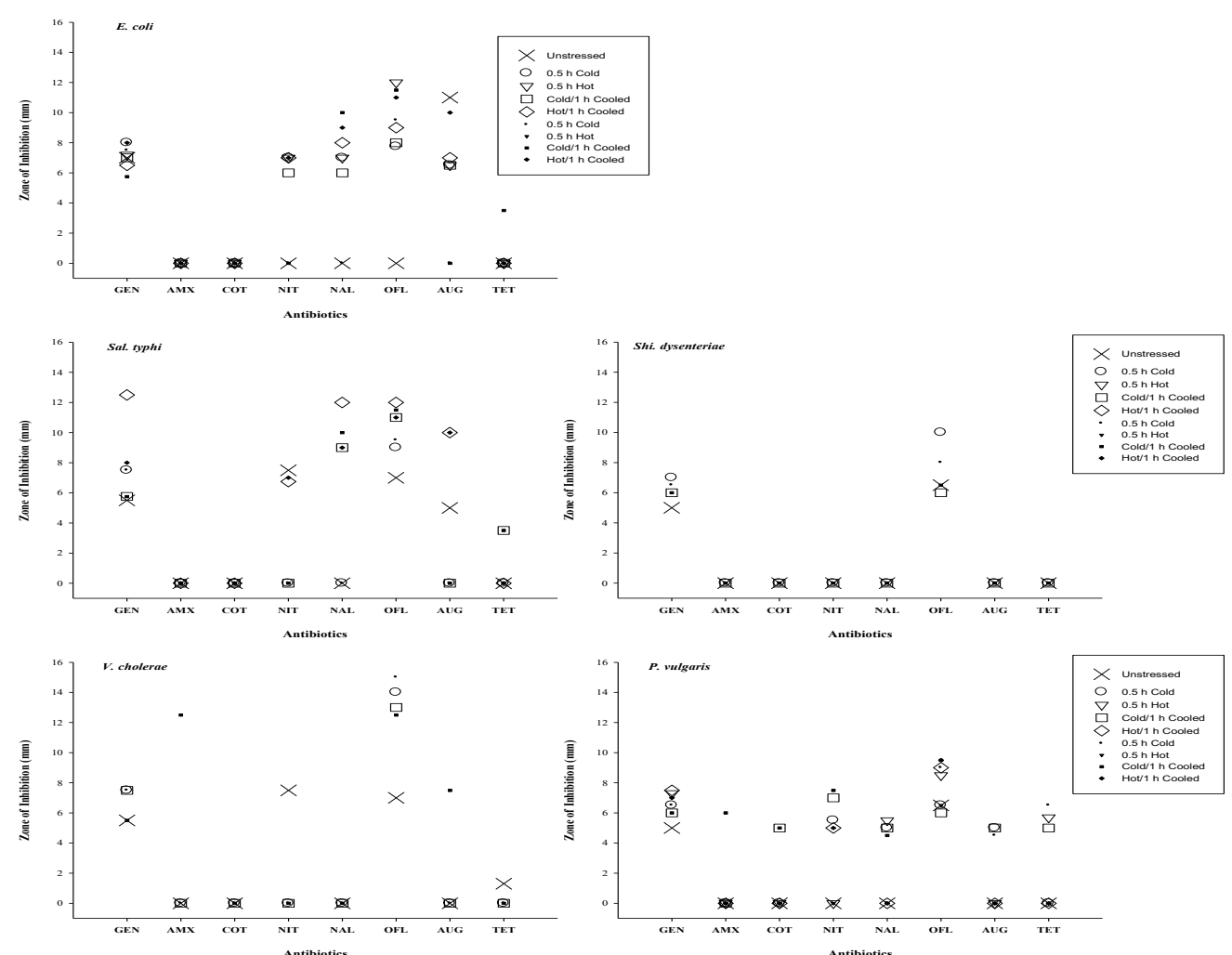

Fig. 2: Effect of temperature stress (cold $=c a .10^{\circ} \mathrm{C}$; hot $=c a .78^{\circ} \mathrm{C}$ ) on antibiotic susceptibility profiles of the unstressed (control) and surviving temperaturestressed test organisms (a) Escherichia coli, (b) Salmonella typhi, (c) Shigella dysenteriae, (d) Vibrio cholerae and (e) Proteus vulgaris. Readings of zones of inhibition were taken $24 \mathrm{~h}(\times, \circ, \square, \nabla, \diamond)$ and $72 \mathrm{~h}(\times, \bullet, \nabla, \mathbf{\square}, \bullet)$, respectively to show if antibiotic action was static or cidal.

A worrying trend is the multiple antibiotic resistance (MAR) exhibited by all the test isolates across board. This is particularly alarming as it not only streamlines the possible treatment regimen and increases the risk of high prevalence of such waterborne diseases, it also brings forth the pervasive nature of antibiotic resistance. This observation is, however, not new as [21] reported the incidence of multiple antibiotic resistant bacteria in drinking water. Similar studies have reported the presence of MAR bacteria in sachet water [22]. It is, however, relieving that none of the test isolates exhibited $100 \%$ resistance to all the antibiotics.

In this study, the results indicate that the euphoria over the safety of water from dispensers, though somehow justified, is perhaps exaggerated. High quality treatment by producers, coupled with good handling practices by users is therefore imperative. Hence, further research to investigate the influence of other factors not within the scope of this study, but thought to have potential effect, such as long-term storage of water in the dispenser bottle and dispenser brand type, is suggested to ensure scientific validity to claims associated with safety of water from dispensers. Such further studies should aim to understand whether the holding temperature and time has significant effect on the type of stress on the bacterial cells.

\section{CONCLUSION}

We present an empirical analysis of the common notion to the microbiological quality of water from dispensers. By inoculating the water with quantified cell loads of 
Escherichia coli, Vibrio sp., Proteus vulgaris, Salmonella typhi, and Shigella sp., subjecting the test isolates to temperature stress by passing through the hot and cold taps, and assessing aliquots of the water for the presence and load of the test isolates, we demonstrated that the notion water dispensers serve as additional water treatment system, though somehow justified, is exaggerated. It was observed that the holding temperatures apparently had an immediate and appreciably inhibitory effect on the pathogens investigated, the effect being greater in the hot water. However, cold temperature and leaving dispensed hot water for over $1 \mathrm{~h}$ before drinking may cause re-inactivation of the injured cells, with some of the stressed pathogens being particularly more resistant to a number of antibiotics. Hence, the unwholesome practice of drinking dispensed water several hours after should be discouraged.

\section{ACKNOWLEDGMENT}

The authors acknowledge the contributions of Oluwakemi Damilola Akinyelure and Sodiq Ranti Abdulfatai to this study.

\section{COMPETING INTEREST}

No competing interests exist.

\section{REFERENCES}

[1] World Health Organization (WHO), Progress on Sanitation and Drinking Water 2010 Update. Geneva, Switzerland: WHO Press, 2010 , pp. 60 . https://www.who.int/water_sanitation_health/ publications/9789241563956/en/

[2] J. M. Rangel, P. H. Sparling, C. Crowe, P. M. Griffin, and D. L. Swerdlow, "Epidemiology of Escherichia coli O157:H7 outbreaks, United State 1982-2002," Emerging Infectious Diseases vol. 11, no. 4, pp. 603-609, April 2005. doi: 10.3201/eid1104.040739. https://pubmed.ncbi.nlm.nih.gov/15829201/

[3] J. Y. Lim, J. Yoon, and C. J. Hovde, "A brief overview of Escherichia coli O157:H7 and its plasmid O157," Journal of Microbiology and Biotechnology vol. 20, no. 1, pp. 5-14, January 2010. https://www.ncbi.nlm.nih.gov/pmc/articles/PMC3645889 /pdf/nihms464337.pdf

[4] C. Masciopinto, R. La Mantia, A. Carducci, B. Casini, A. Calvario, and E. Jatta, "Unsafe tap water in households supplied from groundwater in the Salento Region of Southern Italy," Journal of Water \& Health vol. 5, pp. 129-148, March 2007. doi: 10.2166/wh.2006.054. https://iwaponline.com/jwh/issue/5/1

[5] S. Suthar, S. Singh, and V. Chhimpa, R. K. Bishnoi, I. Saharan, N. Mittal, and V. K. Garg, "The Problem of Safe Drinking Water in Northern Rajasthan, India," Proceedings of the 16th National Symposium on Environment, eds. Puranik, et al., pp. 491-496, India, 2008.

[6] K. Onda, J. LoBuglio, and J. Bartram, "Global access to safe water: accounting for water quality and the resulting impact on MDG progress," International Journal of Environmental Research and Public Health vol. 9, no. 3, pp. 880-894, March 2012. https://doi.org/10.3390/ijerph9030880.

[7] M. Mohsin, S. Safder, F. Asghar, and F. Jamal, "Assessment of drinking water quality and its impact on residents' health in Bahawalpur City," International Journal of Humanities and Social Science vol. 3, no. 15, pp. 114-128, August 2013.

[8] S. P. Luby, A. K. Halder, T. Huda, L. Unicomb, M. S. Islam, B. F. Arnold, and R. B. Johnston, "Microbiological contamination of drinking water associated with subsequent child diarrhea," American Journal of Tropical Medicine and Hygiene vol. 93, no. 5, pp. 904-911, October 2015. doi: https://doi.org/10.4269/ajtmh.15-0274

[9] Clinical and Laboratory Standards Institute (CLSI), Performance Standards for Antimicrobial Susceptibility Testing; Fifteenth
Informational Supplement, M100-S15. Chicago, IL, USA: Clinical and Laboratory Standards Institute Wayne, 2016, Vol. 25, no. 1.

[10] A. Maczulak, Encyclopedia of Microbiology. New York, NY: facts on File Science Library, 2011, pp. 854.

[11] R. S. Shapiro, and L. E. Cowen, "Thermal control of microbial development and virulence: molecular mechanisms of microbial temperature sensing," mBio vol. 3, no. 5, pp. e00238-12, October 2012. doi: $10.1128 / \mathrm{mBio} .00238-12$.

[12] W. H. Coleman, D. Chen, Y. Li, A. Cowan, and P. Setlow, "How moist heat kills spores of Bacillus subtilis," Journal of Bacteriology vol. 189 , no. 23, pp. $8458-8466$, September 2007. doi: $10.1128 / J B .01242-$ 07. https://jb.asm.org/content/189/23/8458

[13] M. Berney, H. Weilenmann, A. Simonetti, and T. Egli, "Efficacy of solar disinfection of Escherichia coli, Shigella flexneri, Salmonella typhimurium and Vibrio cholera," Journal of Applied Microbiology vol. 101, no. 4, pp. 828-836, October 2006. doi: $10.1111 / \mathrm{j} .1365-$ 2672.2006.02983.x.

[14] A. T. Spinks, R. H. Dunstan, T. Harrison, P. Coombes, and G. Kuczera, "Thermal inactivation of water-borne pathogenic and indicator bacteria at sub-boiling temperatures," Water Research vol. 40, no. 6, pp. 1326-1332, March 2006. https://doi.org/10.1016/i.watres.2006.01.032

[15] W. Zhang, and F. A. DiGiano, "Comparison of bacterial regrowth in distribution systems using free chlorine and chloramines: a statistical study of causative factors," Water Research vol. 36, no. 6, pp. 14691482, March 2002. https://doi.org/10.1016/S0043-1354(01)00361-X

[16] J. Schillinger, and S. Du Vall Knorr, "Drinking water quality and issues associated with water vending machines in the city of Los Angeles," Journal Environmental Health vol. 66, no. 6, pp. 25-31, January-February 2004. https://www.jstor.org/stable/44529381

[17] G. Liguori, I. Cavallotti, A. Arnese, C. Amiranda, D. Anastasi, and I. F. Angelillo, "Microbiological quality of drinking water from dispensers in Italy," BioMed Central Microbiology vol. 10, no. 1, pp. 19, January 2010. https://doi.org/10.1186/1471-2180-10-19

[18] B. Levesque, P. Simard, D. Gauvin, S. Gingrad, E. Dewailly, and R. Letarte, "Comparison of the microbiological quality of the water cooler and that of municipal water systems," Applied and Environmental Microbiology vol. 60, no. 4, pp. 1174-1178, April 1994. https://aem.asm.org/content/aem/60/4/1174.full.pdf

[19] K. J. Ryan, and C. G. Ray, Sherris Medical Microbiology, $4^{\text {th }}$ ed. New York: McGraw Hill, 2004, pp. 979.

[20] K. Poole, "Bacterial stress responses as determinants of antimicrobial resistance," Journal of Antimicrobial Chemotherapy vol. 67, no. 9, pp. 2069-2089, September 2012. https://doi.org/10.1093/jac/dks196

[21] J. L. Armstrong, D. S. Shigeno, J. J. Calomiris, and R. J. Seidler, "Antibiotics resistant bacteria in drinking water," Applied and Environmental microbiology vol. 42, no. 2, pp. 277-283, August 1981. https://www.ncbi.nlm.nih.gov/pmc/articles/PMC244002/pdf laem00189-0099.pdf

[22] D. N. Tagoe, L. Adams, and V. Kangah, "Bacterial contamination of Ghanaian currency note: a potential health problem," Journal Microbiology and Biotechnology Research vol. 1, no. 4, pp. 37-44, 2011. 


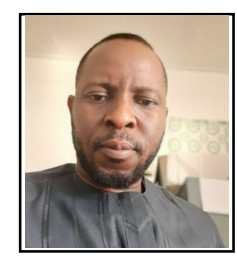

Olusoji Olusegun ADEBISI

Senior Lecturer in Environmental Science and Ecotoxicology.

B.Sc. Microbiology (Unilorin, Nigeria),

M.Sc. Environmental Microbiology (Unilorin Nigeria),

$\mathrm{PhD}$ Environmental Science and Ecotoxicology (Lancaster, UK).

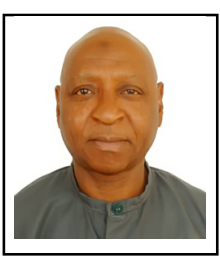

Toyin Olayemi AGBABIAKA

Senior Lecturer in Environmental Microbiology/ Antimicrobials/Nanoparticles.

B.Sc. Microbiology (UniBen, Nigeria), M.Sc. Microbiology (Unilorin, Nigeria),

$\mathrm{PhD}$ Environmental Microbiology (Unilorin, Nigeria).

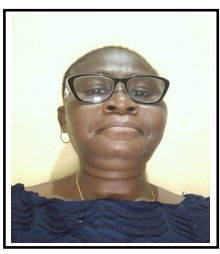

Tayo Modupe KAYODE-ISOLA

Chief Lecturer in Water Microbiology and Environmental Public Health.

B.Sc. Microbiology (Unilorin, Nigeria),

M.Sc. Medical Microbiology (Unilag, Nigeria),

$\mathrm{PhD}$ Environmental Microbiology and Public Health (FUNAAB, Nigeria).

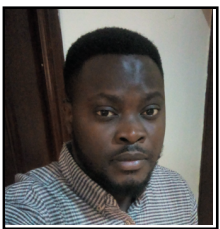

\section{Frank Olakunle OTUYELU}

Doctoral candidate at Department of

Microbiology, University of Ilorin, Nigeria.

B.Sc. Microbiology (Unilorin, Nigeria),

M.Sc. Environmental Microbiology (Unilorin

Nigeria) 